\section{Vitamin D er nødvendig for T-cellerespons mot tuberkulose}

\author{
T-lymfocyttrespons mot Myco- \\ bacterium tuberculosis er kritisk \\ viktig for motstandsevnen. Til- \\ strekkelig konsentrasjon av vita- \\ min D er trolig avgjørende.
}

Mykobakteriene har makrofager som sitt naturlige tilholdssted i tuberkuloseinfiserte individer. Mikroben finnes i fagosomblærene, og blokkerer sammensmelting av fagosomene med lysosomer, som ellers kunne ha satt i gang diverse drapsmekanismer. Det har vært kjent at interferon- $\gamma$, som dannes når T-lymfocytter stimuleres av mykobakterier, har en hovedrolle, men selve mekanismen bak bakteriedrapet har vært ukjent. Mykobakterieinfiserte humane makrofager har ikke latt seg eliminere etter tilsetting av interferon- $\gamma$ til cellekulturer in vitro. Nå foreligger en plausibel mekanisme (1).

Det makrofagkulturene har manglet, har vært tilstrekkelig konsentrasjon av vitamin D. Med sera fra afroamerikanere, som er mer mottakelige for tuberkulose enn hvite amerikanere, ble mykobakteriene ikke drept. Med tilstrekkelig interferon- $\gamma$ og vitamin D inntraff fagosom-lysosom-fusjonen og danningen av de mikrobicidale peptidene cathelicidin og beta-defensin 2 .
- Reseptorer for vitamin D er funnet i praktisk talt alle undersøkte organer. Dette mer enn antyder at vitaminet også har andre funksjoner enn å opprettholde konstant konsentrasjon av kalsium og fosfat i blodet, sier professor emeritus Jan I. Pedersen ved Institutt for medisinske basalfag, Universitetet i Oslo. Vitamin D påvirker f.eks. differensiering av leukocytter og kan ha en veksthemmende effekt på leukemiceller. Det kan spille en rolle for kreft, autoimmune sykdommer, infeksjoner og muskelstyrke. Koblingen til tuberkulose er spesielt interessant. Pioneren Nils Finsen hevdet tidlig at soling påvirket sykdommen i gunstig retning.

- Den nye studien illustrerer hvor komplisert feltet er blitt og åpner nye perspektiver på D-vitaminets funksjoner. Foreløpig har slike nye funn ikke gitt konkret klinisk uttelling eller anbefalinger om høyere inntak av vitamin D, sier Pedersen.

\section{Haakon B. Benestad}

h.b.benestad@medisin.uio.no

Universitetet i Oslo

Litteratur
1. Fabri M, Stenger S, Shin DM et al. Vitamin D is required for IFN- $\gamma$-mediated antimicrobial activity of human macrophages. Sci Transl Med 2011; 3: $104 r a 102$

\title{
Autisme - arv eller miljø?
}

\author{
Ny tvillingstudie setter spørsmåls- \\ tegn ved gamle sannheter om \\ autisme.
}

Synet på årsakene til autisme endret seg dramatisk etter 1977, da en studie av tvillinger viste at eneggede mye oftere enn toeggede var konkordante for tilstanden. Autisme var altså ikke en konsekvens av at «kjøleskapsmødre» hadde avvist babyen, men derimot i høy grad genetisk betinget. I dag regner man med at autisme og autismespekterforstyrrelser har en arvbarhet på omkring $90 \%$. I en ny studie trekker imidlertid forfatterne oppmerksomheten tilbake til miljøfaktorene (1).

I undersøkelsen, som omfattet 192 tvillingpar fra California der minst én i paret hadde autisme eller autismespekterforstyrrelser, beregnet man en arvbarhet på under $40 \%$. Bidraget fra miljøfaktorer delt av tvillingene ble anslått til omkring $50 \%$. I en kommentarartikkel i samme nummer hevdes det at denne undersøkelsen er like betydningsfull som den fra 1977.

- Dette dreier seg om én undersøkelse, med stort frafall og høy grad av statistisk usikkerhet $\mathrm{i}$ resultatene, påpeker Camilla Stoltenberg, assisterende direktør ved Nasjonalt folkehelseinstitutt. Hun er ikke enig $i$ at studien representerer et nytt vendepunkt. Det er åpenbart at gener har stor betydning for autisme, selv om man kan diskutere hvor stor arvbarheten er. I tillegg kan det tenkes at miljøfaktorer fører til de novo-mutasjoner. Dette er mutasjoner som ikke arves fra foreldrene, men oppstår tidlig i fosterlivet. Flere slike mutasjoner som kan knyttes til autisme er oppdaget det siste året ved hjelp av gensekvensering.

- I ABC-studien, et underprosjekt av den norske mor- og barnundersøkelsen, studerer vi blant annet effekter av miljøpåvirkninger i fosterlivet. Hypotesen er at fostre med genetisk sårbarhet kan utvikle autisme dersom de utsettes for uheldige faktorer. Det kan dreie seg om infeksjoner, miljøgifter, medikamenter eller mangel på viktige næringsstoffer, sier Stoltenberg.

\section{Ragnhild Ørstavik}

ragnhild.orstavik@fhi.no

Tidsskriftet

\section{Arne Johan Norheim
arne.johan.norheim@hlkbb.no}

Nasjonalt forskningssenter innen komplementær og alternativ medisin (NAFKAM)

Universitetet i Tromsø

lyser var kroppsmasseindeksen inv korrelert med høyere antall søsken/større husholdninger, mens det var en positiv korrelasjon med høyere utdanning hos foreldrene og høyere inntektsnivå i nabolaget. I den multivariable logistiske regresjonsmodellen

\section{Litteratur}

1. Mushtaq MU, Gull S, Shahid U et al. Family-based factors associated with overweight and obesity among Pakistani primary school children. BMC Pediatr 2011; 11: 114 